\title{
Peran Ghuruh Tolang dalam Menanamkan Nilai Karakter pada Santri di Musholla Al-Ismail Tanah Merah Bangkalan
}

\author{
Abdullah \\ STIT Al Ibrohimy Bangkalan \\ Email: abdie649@gmail.com \\ Moh. Ismail \\ Universitas Sunan Giri Surabaya \\ Email: mohismail09@gmail.com
}

\begin{abstract}
Abstrak
Membincang pendidikan awal di Bangkalan, acap kali dikaitkan dengan ghuruh tolang. Ghuruh tolang adalah figur pendidik yang berperan penting dalam pembentukan karakter dasar anak, namun jarang dikaji dan diteliti. Penelitian deskriptif ini berupaya menganalisis peran ghuruh tolang dalam menanamkan nilai-nilai karakter islami pada santri di musholla al-Ismail Tanah Merah Bangkalan. Hal mendasar yang dilakukan ghuruh tolang adalah mengajari santri membaca al-Qur'an mulai dari mengenalkan huruf hijaiyah hingga dapat membaca al-Qur'an. Temuan penelitian ini memaparkan bahwa masyarakat Madura (dalam hal ini di Tanah Merah Bangkalan) sangat menjunjung tinggi ahklak dan agama, sebab hal itu menjadi petunjuk dalam kehidupan menuju ke arah yang lebih baik. Dengan dasar tersebut, ghuruh tolang menanamkan karakter pada santri yang meliputi tiga aspek, yaitu jasmaniyah, kejiwaan dan kerohanian yang dilakukan secara intensif dan berkesenambungan.
\end{abstract}

Kata Kunci: Ghuruh tolang, pendidikan karakter, pendidikan Islam

\section{Pendahuluan}

Fenomena yang sering terjadi di Indonesia kasus perilaku menyimpang dari nilai-nilai ajaran agama Islam seperti kriminalitas, pelecehan seksual, free sex atau pergaulan bebas dan lain-lain. Lebih parah lagi, pelaku dari kasus-kasus tersebut dilakukan oleh kalangan remaja muslim yang berpendidikan. Orang Islam seyogyanya menunjukkan perilaku yang sesuai dengan nilai-nilai ajaran agama Islam yaitu nilai-nilai dalam tingkah laku yang seharusnya dijadikan sebagai acuan dalam kehidupan sehari-hari oleh manusia muslim baik bertindak sebagai individu, keluarga, masyarakat atau warga negara. Setiap pribadi 
muslim dituntut untuk dapat menjadikan tingkah laku dalam kehidupan sehari-hari sebagai cermin dari nilai-nilai akhlak dalam Islam.

Selanjutnya, bagaimana nilai-nilai ajaran Islam tersebut dapat diaplikasikan dalam perilaku sehari-hari sehingga mampu mempengaruhi dan mewarnai pola kepribadian, selanjutnya menggejala dalam perilaku lahiriyah. Dalam hal ini dibutuhkan sarana yang efisien dan efektif adalah pendidikann Islam.

Selain itu pendidikan merupakan sarana atau alat untuk merealisasikan hidup orang muslim secara maksimal. Pendidikan Islam merupakan salah satu sarana untuk dapat dilaksanakannya nilai-nilai akhlak dalam Islam oleh pribadi-pribadi muslim sehingga mampu meminimalisir jumlah muslim terdidik yang miskin akan nilai-nilai akhlak dalam Islam dalam kepribadiannya. Nilai-nilai yang hendak dikembangkan dalam pribadi anak didik adalah nilai-nilai kultural bangsa Indonesia dan nilai keagamaan. Nilai keagamaan tentunya tidak mengkhususkan nilai agama tertentu, tetapi sesuai dengan agama yang dianut oleh setiap warga negara.

Pendidikan Islam harus ditujukan ke arah pertumbuhan yang berkesinambungan dari kepribadian manusia yang menyeluruh melalui latihan spiritual, kecerdasan dan rasio, perasaan dan panca indra, oleh karenanya maka pendidikan harus memberikan pelayanan kepada pertumbuhan manusia dalam semua aspeknya. Yaitu aspek spiritual, intelektual, imajinasi, jasmaniah, ilmiah, linguistik baik secara individual maupun secara kolektif serta mendorong semua aspek itu kearah perbaikan dan pencapaian kesempurnaan. ${ }^{1}$

Dalam konteks pendidikan Islam, maka yang menjadi sasaran dalam pengembangan tersebut adalah nilai-nilai akhlak Islami yang menyatu dalam kepribadian. Nabi Muhammad sendiri sebagai pembawa agama Islam, menjalankan misi menyempurnakan akhlak yang mulia sebagaimana dalam haditsnya:

$$
\text { بعثت لإ تمم حسن الاخلاق (رو اه ما للك)2 }
$$

Aku diutus untuk menyempurnakan akhlaq yang bagus. (HR. Malik)

Athiyah al-Abrasi berpendapat bahwa pendidikan budi pekerti dan akhlak merupakan jiwa pendidikan Islam dan mencapai akhlak yang sempurna merupakan tujuan sebenarnya dari pendidikan Islam. ${ }^{3}$

${ }^{1}$ H.M. Arifin, Filsafat Pendidikan Islam (Jakarta: Bumi Aksara, 1996), Cet. 5, 132. ${ }^{2}$ Imam Malik bin Anas, Al-Muwatta` (Beirut: Dar al-Fikr, 1422 H), Cet. 3, 552.

${ }^{3}$ Athiyah al-Abrosi, Dasar-Dasar Pokok Pendidikan Islam (Jakarta: Bulan Bintang, 1970), 90. 
Uraian di atas menunjukkan bahwa idealnya pendidikan Islam harus concern terhadap persoalan bagaimana mengubah pengetahuan agama yang bersifat kognitif menjadi "makna" yang perlu di internalisasikan dalam diri peserta didik, untuk selanjutnya menjadi sumber motivasi bagi peserta didik untuk bergerak, berbuat dan berperilaku secara konkret agamis dalam kehidupan sehari-hari.

Pendapat Senada Arifin mengatakan proses kependidikan anak, yang dikehendaki oleh Islam untuk mencapai sasaran dan tujuan akhir, nilai-nilai Islam akan mendasari dan lebih lanjut akan membentuk corak kepribadian anak didik, pada masa dewasanya. ${ }^{4}$ Yang berkaitan dengan pendidikan nilai, secara natural manusia adalah sebagai mahluk yang memiliki posisi unik. Posisi tersebut terletak pada dualisme moral. ${ }^{5} \mathrm{Di}$ satu pihak terdapat keinginan pada hal-hal yang bersifat positif, sedang dipihak lain cenderung pada hal-hal yang tidak baik.

Era globalisasi merupakan ancaman yang cukup serius terhadap runtuhnya nilai, menjadikan generasi muda bangasa dengan mudah mengakses apapun yang dilakukan oleh siapaun baik di Indonesia atapun di Negara lain, sehingga peniruan tanpa penyeleksianpun tak terelakkan. Seiring pesatnya laju teknologi, globalisasi disegala bidang dan kemajemukan, sehingga kompleksitas persoalan manusia pun semakin bermunculan.

Rose Pole, seperti yang dikutip Tafsir dalam bukunya menyatakan: It is that the modern world call into existence certain conception of morality, but also destroys the ground for taking them seriously. Modernity both needs morality. And makes of impossible. (Dunia modern ini memunculkan konsep-konsep moralitas tertentu, namun juga sebaliknya, mencabut alasan-alasan untuk menerima konsep-konsep tersebut. Modernitas membutuhkan moralitas, dan juga membuat moralitas menjadi mustahil). ${ }^{6}$

Dua potensi manusia (posisi unik) di atas dihadapkan dengan era modern menjadikan salah satu dari dua potensi tersebut, yaitu kecenderungan terhadap hal-hal negatif mendapatkan peluang besar untuk muncul dipermukaan. Dalam era modern manusia banyak ditawari dengan kemudahan, termasuk di dalamnya kemudahan-kemudahan yang dapat mengantarkan pada perilaku-perilaku negatif. Oleh karena itu penanaman nilai-nilai agama pada santri menjadi sesuatu yang penting, serius dan tidak dapat diremehkan Kehidupan dan pertumbuhan anak

\footnotetext{
${ }^{4}$ Arifin, Filsafat Pendidikan Islam, 33.

${ }^{5}$ Tafsir, at. al., Moralitas Al-qur'an Dan Tantangan Modernitas (Yogyakarta: Gama Media, 2003), 2.

${ }^{6}$ Ibid., 2.
} 
pada masyarakat terbelakang seperti itu tidak dapat disepelehkan, karena kemajuan ilmu pengetahuan dan teknologi telah berkembang pesat, sehingga kepandaian dan keterampilan tidak mungkin lagi berpindah dari generasi tua kepada generasi muda melalui pengalaman hidup dari orang tua saja, tetapi harus dengan pendidikan oleh orang yang mempunyai kemampuan dan keterampilan untuk itu ${ }^{7}$, yaitu ghuruh tolang. ${ }^{8}$

Ghuruh tolang adalah orang yang bekerja dalam bidang pendidikan dan pengajaran, yang ikut bertanggung jawab dalam mendidik dan mengajar, membantu anak untuk mencapai kedewasaan. ${ }^{9}$ Ghuruh tolang dalam pandangan masyarakat adalah orang yang melaksanakan pendidikan di tempat-tempat tertentu, tidak terbatas di lembaga pendidikan formal, tetapi bisa juga di masjid, mushala, di rumah dan sebagainya.

Ghuruh tolang memang menempati kedudukan yang terhormat di masyarakat. Peranan dan kewibawaan yang menyebabkan seorang ghuruh tolang dihormati, sehingga masyarakat tidak meragukan figur seorang guru tulang. Masyarakat yakin bahwa peran ghuruh tolang yang mendidik mereka agar menjadi orang yang berkepribadian mulia. Ghuruh tolang adalah komponen yang penting dalam pendidikan, yakni orang yang bertanggung jawab mencerdaskan kehidupan anak didik, dan bertanggung jawab atas segala sikap, tingkah laku dan perbuatan dalam rangka membina anak didik agar menjadi orang yang bersusila yang cakap, berguna bagi nusa dan bangsa di masa yang akan datang.

Peran ghuruh tolang dalam mendidik dan membimbing mempunyai pengaruh terhadap santri, pengaruh tersebut akan terjadi melalui pendidikan dan pengajaran yang dilakukan baik dengan sengaja, maupun tidak sengaja oleh ghuruh tolang, melalui sikap, gaya, dan macam-macam penampilan kepribadian guru tulang. Dapat dikatakan, bahwa kepribadian guru tulang akan lebih besar pengaruhnya dari pada kepandaian dan ilmunya, terutama bagi anak didik yang masih dalam usia kanak-kanak dan masa meningkat remaja, yaitu tingkat pendidikan dasar dan menengah, karena anak didik pada tingkat tersebut masih dalam masa pertumbuhan dan perkembangan kepribadiannya.

Pandangan tentang citra guru tulang sebagai orang yang wajib digugu (dipatuhi) dan ditiru (diteladani) tidak perlu diragukan kebenarannya, konsep klasik tersebut mengandaikan pribadi guru tulang

${ }^{7}$ Zakiah Darajat, Kepribadian Guru (Jakarta: Bulan Bintang, 1978), 7.

${ }^{8}$ Ghuruh tolang adalah guru yang pertama mengajarkan ilmu agama, kebanyakan masyarakat di Bangkalan, menyerahkan anaknya ke langgar untuk didik oleh kiai lokal pendidikan agama Islam.

${ }^{9}$ Abuddin Nata, Filsafat Pendidikan Islam (Jakarta: Logos Wacana Ilmu, 1997), 62.

132 Jurnal El-Banat 
serta perbuatan kependidikan tanpa cela, sehinga pantas hadir sebagai manusia model yang ideal. Hal ini tidak sesuai dengan kenyataan.

Pendidik yang pertama dan utama adalah orang tua (ayah dan ibu), karena adanya pertalian darah yang secara langsung bertanggung jawab penuh atas kemajuan perkembangan anak kandungnya, karena sukses anaknya merupakan sukses orang tua juga. Orang tua disebut pendidik kodrati. Apabila orang tua tidak punya kemampuan dan waktu untuk mendidik, maka mereka menyerahkan sebagian tanggung jawabnya kepada orang lain atau lembaga pendidikan yang berkompetensi untuk melaksanakan tugas mendidik.

\section{Nilai-nilai Karakter dalam Islam}

Nilai disebut norma, yang berasal dari kata Latin dengan arti Literal "siku-siku tukang kayu" (carpenter's square). ${ }^{10}$ Untuk mendapatkan ukuran yang tepat seperti sudut, garis lurus, maka seorang tukang kayu menggunakan alat yang disebut siku-siku. Jadi, nilai sebagai norma adalah standar yang tepat untuk mengukur sesuatu. Kejujuran misalnya, adalah sebuah nilai, tetapi yang mengatur tentang sikap jujur tersebut dalam kondisi tertentu disebut norma. Sedangkan norma kejujuran adalah aturan tingkah laku yang digunakan seseorang dalam pergaulan hidup seperti transaksi bisnis, pertemanan, pendidikan dan sebagainya.

Nilai-nilai disebut juga "qiyam" kata mufradnya "qimah" yaitu harga atau kadar. ${ }^{11}$ Nilai sesuatu tergantung dari harga atau kadar yang dikandungnya. Dalam bahasa Arab disebutkan "lifulanin qimatun" (orang itu tidak bernilai) bila ia tidak mempunyai konsisten dan berketepatan dalam urusan (masalah "lahu stabatun wadawamun 'ala al-amr"). Karena itu, konsistensi dan istiqamah termasuk nili-nilai kemanusiaan yang tinggi. Nilai-nilai islam antara lain adalah iman, tauhid, islam, taqwa, ihsan, tawakal, istiqamah, ma'ruf, persaudaraan, keadilan, kebenaran, kejujuran, keikhlasan, kesabaran, ketekunan, ketaatan, bekerja, kecintaan, berusaha, kesyukuran, solidaritas dan sebagainya.

Hidup yang memililki nilai semakin dicari orang. Karena ritualritual yang sifatnya monoton, masih juga belum memberikan makna hidup yang bernilai bagi kebanyakan orang. Kehendak untuk hidup yang bermakna merupakan inovasi utama setiap orang. Dalam batas-batas tententu manusia memiliki kebebasan dan tanggung jawab pribadi untuk memilih dan menentukan makna dan tujuan hidupnya.

10 Syafii Ma'arif, Islam dan Pengembangan Ilmu (Yogyakarta: PT. Surya Sarana Utama Divisi Grafika, 2003), 157.

${ }^{11}$ Ibid, 158. 
Hidup yang bernilai, menurut Muhaimin dapat diperoleh dengan merealisasikan tiga nilai kehidupan. Pertama, creative values (nilai-nilai kreatif), yakni bekerja dan berkarya serta melaksanakan tugas dengan tanggung jawab penuh pada pekerjaan. Sebenarnya, pekerjaan merupakan sarana yang dapat memberi kesempatan untuk menemukan dan mengembangkan makna hidup. Makna hidup bukan terletak pada pekerjaan melainkan pada tata cara yang mencerminkan keterlibatan pribadi pada pekerjaan. Berbuat kebajikan dan melakukan hal-hal yang bermanfaat bagi lingkungan termasuk usaha dalam merealisasikan nilainilai kreatif. Kedua, experiental values (nilai-nilai penghayatan), yakni menghayati dan meyakini kebenaran, kebajikan , keindahan, keimanan dan nilai-nilai yang lain yang dianggap berharga. Dalam hal ini cinta kasih merupakan nilai yang sangat penting dalam mengembangkan hidup yang bermakna. Mencintai seseorang berarti menerima sepenuhnya keadaan orang yang dicintai apa adanya serta benar-benar memahami kepribadiannya dengan penuh pengertian. Ketiga, attudinal values (nilainilai bersikap), yakni menerima dengan tabah dan mensikapi dengan tepat penderitaan yang tak bisa dihindari lagi, setelah berupaya keras mengatasinya tetapi tetap tidak berhasil. Mengingat peristiwa tragis tak bisa dielakkan lagi, maka sikap dalam menghadapinyalah yang harus dirubah. Dengan mengubah sikap diharapkan beban mental akibat musibah menjadi berkurang, dan bisa menemukan hikmah dibaliknya. Penderitaan memang dapat mmberikan makna apabila dapat merubah penderita menjadi lebih baik sikapnya. Optimis dalam menghadapi musibah ini tersirat dalam ungkapan-ungkapan, seperti makna dalam derita. $^{12}$

Milton Rokeach dan James Bank berpendapat bahwa nilai merupakan Suatu tipe kepercayaan yang berada dalam ruang lingkup system kepercayaan, dalam mana seeorang bertindak atau menghindari suatu tindakan, atau mengenai sesuatu yang pantas atau tidak pantas dikerjakan. ${ }^{13}$

Dari pengertian tersebut diatas dapat dipahami bahwa nilai merupakan sifat yang melekat pada sesuatu system kepercayaan yang telah berhubungan dengan subyek yang memberi arti, yakni manusia yang meyakini. Pengertian nilai menurut J.R Frankle adalah: "A value is an idea a concept about what some one thinks is important inlife ${ }^{\text {"It }}$ Sidi Gazalba mengartikan nilai sebagai berikut:

\footnotetext{
${ }^{12}$ Muhaimin, Paradigma Pendidikan Islam (Bandung: Rosda Karya, 2002), 291.

${ }^{13}$ Kratwohl dalam Chabib Thaha, Kapita Selekta Pendidikan Islam (Yogyakarta: Pustaka Pelajar, 1996), 60.

14 Thaha, Kapita Selekta, 60.
}

134 Jurnal El-Banat 
Nilai adalah sesuatu yang bersifat abstrak, ia ideal, nilai bukan benda konkrit, bukan fakta, tidak hanya persoalan benar dan salah yang menuntut pembuktian empirik, melainkan soal penghayatan yang dikehendaki, disenangi dan tidak disenangi. ${ }^{15}$

Dari pengertian tersebut, menurut penulis nilai merupakan esensi yang melekat pada sesuatu yang sangat berarti bagi kehidupan manusia. Esensi belum akan berarti sebelum di butuhkan oleh manusia, tetapi tidak berarti bahwa adanya esensi karena adanya manusia yang membutuhkan. Hanya saja makna esensi akan semakin meningkat sesuai dengan peningkatan daya tangkap dan pemaknaan manusia itu sendiri.

Nilai dapat dilihat dari berbagai sudut pandang, yang menyebabkan terdapat macam-macam nilai, antara lain: ${ }^{16}$

1. Dilihat dari segi kebutuhan manusia, nilai menurut Abraham Maslaw dapat dikelompokkan menjadi: a) nilai biologis; b) nilai keamanan; c) nilai cinta kasih; d) nilai harga diri; e) nilai jati diri.

Kelima nilai tersebut berkembang sesuai dengan tuntunan kebutuhan. Dari kebutuhan yang paling sederhana, yakni kebutuhan tuntunan akan fisik biologis, keamanan, cinta kasih, harga diri dan yang terakhir adalah kebutuhan jati diri. Namun kebutuhan akan suatu nilai kehidupan yang bermakna sebagaimana dikemukakan oleh Abraham Maslaw menjadi keliru jika dikaitkan dengan nilai keagamaan. Sebagaimana nilai urutan diatas menimbulkan suatu pertanyaan, apkah untuk menemukan jati diri sebagai orang muslim dan mukmin yang baik itu baru dapat terwujud setelah kebutuhan yang lebih rendah tercukupi terlebih dahulu? Misalnya makna cukup, tidak ada yang merongrong dalam beragama, dicintai dan di hormati orang baru dapat beriman dengan baik, tentunya tidak. Nilai keimanan dan ketaqwaan tidak tergantung pada kondisi ekonomi maupun sosial budaya, tidak tergantung oleh dimensi ruang dan waktu.

2. Dilihat dari kemampuan jiwa manusia untuk menangkap dan mengembangkan nilai dapat dibedakan menjadi dua yakni: a) Nilai yang statis, seperti kognisi, emosi dan psikomotor; dan b) Nilai yang bersifat dinamis, seperti motivasi berprestasi, motifasi brafiliasi, motivasi berkuasa. ${ }^{17}$

\footnotetext{
${ }^{15}$ Sidi Gazalba, Sistematika Fisafat (Jakarta: Bulan Bintang, 1978), 89.

16 Thaha, Kapita Selekta, 61.

${ }^{17}$ Noeng Muhajir, Ilmu Pendidikan dan Perubahan Sosial; Suatu Teori Pendidikan (Yogyakarta: Rake Sarasin), 83.
} 
3. Pendekatan proses budaya sebagaimana dikemukakan oleh Abdullah Sigit, nilai dapat dikelompokkan dalam tujuh jenis yakni: a) nilai ilmu pengetahuan; b) nilai ekonomi; c) nilai keindahan; d) nilai politik; e) nilai keagamaan; f) nilai kekelurgaan; g) nilai kejasmanian.

Pembagian nilai-nilai ini merupakan nilai dasar proses terbentuknya kebudayaan manusia yang mencakup hubungan manusia dengan Tuhannya, hubungan manusia dengan manusia, dan hubungan manusia dengan dirinya sendiri. Dengan demikian, nilai-nilai itu mencakup nilai-nilai ilahiyah dan insaniyah.

4. Nilai bila dilihat dari sifat nilai itu sendiri dapat dibagi dalam: a) Nilainilai subyektif yakni nilai yang merupakan reaksi subyek terhadap obyek, hal ini sangat tergantung pada masing-masing pengalaman subyek tersebut. b) Nilai-nilai obyektif rasional yakni nilai-nilai yang merupakan esensi dari obyek secara logis yang dapat diketahui melalui akal sehat. Seperti nilai kemerdekaan, nilai kesehatan, nilai keselamatan, nilai perdamaiaan dan lain sebagainya. c) nilai-nilai obyektif metafisik yakni nilai yang mampu menyusun kenyataan obyektif seperti nilai agama.

5. Nilai bila dilihat dari sumbernya terdapat: a) Nilai ilahiyah yakni nilai yang bersumber dari wahyu (Allah), b) Nilai insaniyah yakni nilai yang diciptakan manusia atas dasar kriteria yang diciptakan pula oleh manusia. ${ }^{18}$ Nilai-nilai ilahiyah adalah nilai-nilai yang didasarkan pada Al-quran dan Al-Hadis yang mencakup ajaran agama islam seperti, akidah (iman), syari'ah(islam) dan akhlak(ihsan). Sedangkan "Al Qiyam Al Insaniyah" (nilai-nilai kemanusiaan) adalah nilai-nilai yang tegak berdasarkan penghormatan terhadap hak-hak asasi dan kemuliaan manusia. Baik kebebasan dan kemerdekaannya, nama baik dan eksistensinya, kehormatannya dan hak-haknya, dan juga memelihara darahnya, hartanya serta kerabat keturunannya dalam kedudukan mereka sebagai individu anggota masyarakat. ${ }^{19}$

6. Dilihat dari ruang lingkup dan keberlakuannya, nilai dibagi: a) Nilainilai universal. b) nilai-nilai lokal.

\footnotetext{
${ }^{18}$ Muhajir, Ilmu Pendidikan, 84.

${ }^{19} \mathrm{http}$ ///media.isnet.org/islam/Qardhawi/Masyarakat/NilaiKemanusiaan.html.

Diakses pada 22 September 2019.
} 
7. Nilai dilihat dari segi hakekatnya, tediri dari: a) Nilai hakiki, bersifat universal dan abadi. b) Nilai instrumental, bersifat lokal, pasang surut dan temporal.

Proses pembentukan nilai pada anak dapat dikelompokkan dalam 5 tahap:

a. Tahap receiving (menyimak), pada tahap ini seseorang secara aktif dan sensitif menerima stimulus dan menghadapi fenomenafenomena, sedia menerima secara aktif dan selektif dalam memilih fenomena. Pada tahap ini nilai belum terbentuk melainkan baru menerima adanya nilai-nilai itu untuk dipilih mana yang paling menarik bagi dirinya.

b. Tahap responding (menanggapi), dimana seseorang mulai bersedia menerima dan menanggapi secara aktif stimulus dalam bentuk respon yang nyata. Dalam tahap ini ada tiga tingkatan yakni tahap compliance (manut), willingness to respond (sedia menghadapi) dan satisfacationin response (puas dalam menanggapi). Tahap ini seseorang sudah mulai aktif menanggapi nilai-nilai yang berkembang diluar dan meresponnya.

c. Tahap valuing (memberi nilai), kalau dalam tahap pertama dan kedua lebih banyak masih bersifat aktifitas fisik biologis dalam menerima dan menanggapi nilai, maka pada tahap ini seseorang sudah mampu menangkap stimulus itu atas dasar nilai-nilai yang terkandung didalamnya, ia mulai mampu menyusun persepsi tentang obyek. Dalam hal ini terdiri dari tiga tahap, yakni percaya pada nilai yng ia terima, merasa terikat dengan nilai yang dipercayai (dipilihnya) itu, dan memililki keterikatan batin (commitment) untuk memperjuangkan nilai-nilai yang diterima dan diyakini itu.

d. Tahap mengorganisasikan nilai (organization), yakni satu tahap yang lebih kompleks dari tahap ketiga diatas. Seseorang mulai mengatur sistem nilai yang ia terima dari luar untuk diorganisasikan dalam dirinya sehingga sitem nilai itu menjadi bagian yang tidak terpisahkan dalam dirinya sendiri. Pada tahap ini ada dua tah organisasi nilai dalam dirinya, yakni mengkonsepsikan nilai dalam dirinya dan mengorganisasikan sistem nilai dalam 
dirinya yakni cara hidup dan tata perilakunya sudah didasarkan atas nilai-nilai yang diyakininya.

e. Tahap karakterisasi nilai, pada tahap ini seseorang telah mampu mengorganisir sistem nilai yang diyakini dalam hidupnya secara mapan, ajeg dan konsisten sehingga tidak dapat dipisahkan lagi dengan pribadinya. Pada tahap ini bila dipisahkan terdiri dari dua tahap yang lebih kecil yakni tahap menerapkan sistem nilai dan tahap karakterisasi yakni tahap mempribadikan sistem nilai tesebut. $^{20}$

\section{Ghuruh tolang dalam Pandangan Masyarakat Bangkalan}

Ghuruh tolang merupakan seorang guru yang pertama kali mengajarkan ngaji al-Quran, mulai dari mengajari huruf hijaiyah, perkata sampai santri bisa membaca al-Quran dengan lancar sesuai dengan bacaan al-Quran dengan tajwidnya, istilah ghuruh tolang sendiri diistilahkan oleh masyarakat Madura terhadap guru ngaji pertama anaknya. Ghuruh tolang menyediakan langger ${ }^{21}$ di rumahnya sebagai tempat belajar mengaji, tidak meminta bayaran ke santri atau menentukan SPP, karena ghuruh tolang mengajar santrinya dengan keikhlasan dan ketulusan, akan tetapi santri dengan suka rela menentukan urunan seminggu sekali setiap malam kamis untk membayar listrik secara sukarela. Santri berangkat ngaji sebelum azdan magrib sekitar jam 17.10. Proses pembelajaran dimulai dengan sholat magrib berjamaan, kemudian dilanjutkan belajar mengaji dengan metode sorokandan diakhiri solat isya' berjamaah, ngaji libur setiap hari kamis atau malam jumat. Sedangkan cara orang tua biasanya menitipkan anaknya ke ghuruh tolang untuk diajari ngaji mulai sekitar usia 3 tahun sampai sekitar umur 13 tahun setelah itu santri pindah ngaji ke masjid husus melancarkan bacaan. ${ }^{22}$

Ghuruh tolang merupkan orang yang paham tentang ajaran Islam, terkait tempat mengaji sebenarnya tidak secara resmi dibentuk, terkadang tebentuk secara tidak langsung karena seringnya ada anakanak yang bermain atau orang yang mengajari cucu-cucu nya, kemudian

${ }^{20}$ David R. Krathwohl dalam Chabib Thaha, Kapita Selekta, 72.

${ }^{21}$ Istilah Langger merupakan mosollah peribadi, di Banggalan setiap rumah memiliki langgar yang multifungsi digunakan sebagai tempat ibadah, istirahat sehababis pulang dari sawah, sebagai tempat menerima tamu dan tempat hajatan, tapi tidak semua langgar digunakan sebagai tempat belajar mengajar.

${ }^{22}$ Imam Mawardi, Wawancara, Bangkalan 04 mei 2019. 
ada orang yang matorok $^{23}$ anaknya untuk diajari ngaji kemudian para tetangga juga mengikutinya. Ghuruh tolang mengajari mengaji dari menggunakan torroden ${ }^{24}$ sampai al Qu'ran. Jika sudah khatam biasanya wali santri selametan yang diletakkan ditempat ngaji dan biasanya jumlah santri biasanya 10-20 santri. Selain itu guru tulang menanamkan nilai-nilai- keagamaan sebelum dimasukkan ke Madrasah Diniyah atau ke pondok pesantren. Oleh karena itu ghuruh tolang akan mengadapi karakter yang berbeda-beda, maka guru tolong harus bisa menyesuaikan diri, seorang guru tidak boleh terlalu sensitif atau lekas marah dan penakut, artinya seorang guru dapat menstabilkan emosi. Hal ini sesuai dengan tugas seorang pendidik.

Dalam paradigma Jawa, pendidik diidentikkan dengan guru, yang mempunyai makna "Digugu dan ditiru" artinya mereka yang selalu dicontoh dan dipanuti. Sedangkan dalam kamus besar bahasa Indonesia adalah seorang yang pekerjaannya (mata pencahariannya, profesinya) mengajar. Dalam bahasa Arab disebut mu'allim dan dalam bahasa Inggris disebut Teacher. Itu semua memiliki arti yang sederhana yakni "A Person Occupation is Teaching Other" artinya guru ialah seorang yang pekerjaannya mengajar orang lain. ${ }^{25}$

Adapun literatur kependidikan Islam, seorang guru biasa disebut sebagai ustadz, mu'allim, murabbiy, mursyid, mudarris dan mu'addib. Kata $u s t a d z$ biasa digunakan untuk memanggil seorang profesor. Ini mengandung makna bahwa seorang guru dituntut untuk komitmen terhadap profesionalisme dalam mengemban tugasnya. Kata mu'allim berasal dari kata dasar 'ilm yang berarti menangkap hakikat sesuatu. Dalam setiap 'ilm, terkandung dimensi teoritis dan dimensi amanah. Ini mengandung makna bahwa seorang guru dituntut untuk mampu menjelaskan hakikat ilmu pengetahuan yang diajarkannya, serta menjelaskan dimensi teoritis dan praktisnya, dan berusaha membangkitkan peserta didik untuk mengamalkannya.

Kata murabbiy berasal dari kata dasar rabb. Tuhan adalah sebagai rabb al-'alamin dan rabb al-nas. Yakni yang menciptakan, mengatur dan memelihara alam seisinya termasuk manusia. Dilihat dari pengertian ini maka tugas guru adalah mendidik dan menyiapkan peserta didik agar mampu berkreasi, sekaligus mengatur dan memelihara hasil kreasinya untuk tidak menimbulkan malapetaka bagi dirinya, masyarakat

${ }^{23}$ Orang tua mendaftarkan anaknya dengan istilah matorok (nitip), biasanya cukup membawa sebungkus sembako seperti beras dan gula dll.

${ }^{24}$ Torroden adalah kitab yang isinya tentang huruf hijaiyah dan surat-surat pendek.

${ }^{25}$ Muhibbin Syah, Psikologi Pendidikan Suatu Pendekatan Baru (Bandung: Remaja Rosda Karya, 1995), 233. 
dan alam sekitarnya. Kata mursyid biasa digunakan untuk guru dalam thariqah (tasawuf). Dengan demikian seorang mursyid (guru) berusaha menularkan penghayatan akhlak dan atau kepribadiannya kepada peserta didiknya baik yang berupa etos ibadahnya, etos kerjanya, etos belajarnya maupun dedikasinya yang serba lillaahi ta'ala. Kata mudarris berasal dari akar kata darasa-yadrusu-darsan-wa durusan-wa dirasatan, yang berarti terhapus, hilang bekasnya, menghapus, menjadikan usang, melatih, mempelajari, dilihat dari pengertian ini maka tugas guru adalah berusaha mencerdaskan peserta didiknya, menghilangkan ketidak tahuan atau memberantas kebodohan mereka, serta melatih keterampilan mereka sesuai dengan bakat, minat dan kemampuannya.

Sedangkan kata mu'addib berasal dari kata $a d a b$, yang berarti moral, etika dan adab atau kemajuan lahir dan batin. Sehingga guru adalah orang yang beradab sekaligus memiliki peranan dan fungsi untuk membangun peradaban yang berkualitas di masa depan ${ }^{26}$ Adapun dalam buku Filsafat Pendidikan Islam, mengatakan pendidik adalah orang dewasa yang bertanggung jawab memberi bimbingan atau bantuan kepada anak didik dalam perkembangan jasmani dan rohaninya agar mencapai pendidikan bahasa arab kedewasaan, mampu melaksanakan tugasnya sebagai makhluk Allah, khalifah di permukaan bumi, sebagai makhluk sosial dan sebagai individu yang sanggup berdiri sendiri ${ }^{27}$.

Dalam hal ini H.M .Arifin yang mengutip pendapat Imam Ghozali mengatakan: para guru memiliki adab yang baik, karena anak selalu melihat gurunya sebagai contoh yang diikuti, yang mana hal ini harus di insyafi olrh guru, mata murid selalu tertuju kepadanya dan telinga mereka selalu mendengar tentang dirinya. Maka lalu anggapan sesuatu itu baik berarti baik pula dimata mereka dan apabila anggapan itu jelek berarti jelek pula dimata mereka. ${ }^{28}$

Dari pendapat diatas dapat diambil suatu pengertian bahwa segala sesuatu yang diajarkan oleh guru agama disadari maupun tidak adalah merupakan cerminan bagi anak oleh karena itu tingkah laku atau gerak-gerik seorang guru yang berbudi luhur setidak-tidaknya dapat mempengaruhi perkembangan anak didik terhadap pelajarannya. Disamping itu guru harus mempunyai dedikasi terhadap tugasnya, pemaaf dan berbuat aduil, karena pelaksanaan pendidikan sangat

${ }^{26}$ Muhaimin, Pengembangan Kurikulum Pendidikan Agama Islam (Jakarta: PT Raja Grafindo, 2005), 44-49.

${ }^{27}$ Hamdani Ihsan, Fuad Islam, Filsafat Pendidikan Islam (Bandung: CV Pustaka Setia, 2001), 93.

${ }^{28}$ H.M. Arifin, Hubungan Timbal Baik Pendidikan Agama, Keluarga, dan Sekolah (Jakarta: Bulan Bintang, 1989), 127. 
diperlukan sekali adanya. Hal tersebut diatas terutama perbuatan adil para guru sebab dengan demikian seorang guru akan mendapat kepercayaan penuh dari muridnya.

Berdasarkan tanggung jawab guru diatas bahwa pada dasarnya tanggung jawab guru agama adalah sangat berat, sebab guru sangat bertanggung jawab atas berhasilnya pendidikan dan pengajaran sehingga anak didiknya menjadi orang yang bersyukur yang mana akan menjadikan mereka mendapat kebahagiaan dunia akhirat. Sebagaimana dijelaskan dalam hadits Nabi SAW di bawah ini, yaitu:

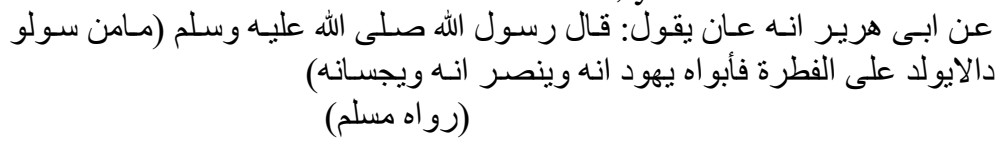

"Dari Abi Hurairah ra: Sesungguhnya Rasulullah SAW bersabda: tidaklah seorang anak itu dilahirkan melainkan dalam keadaan suci, kedua orang tuanya yang dapat menjadikan ia beragama Yahudi, Nasrani atau majusi". ${ }^{29}$

Dengan demikian jelas bahwa peran dan tanggung jawab atas keberhasilan pendidikan dan pengajaran dituntut pula harus mampu menumbuhkan kekuatan iman pada anak didiknya sehingga menjadikan anak didik tersebut pandai bersyukur yang ada pada akhirnya akan dapat membahagiakan diri anak tersebut yakni kebahagiaan dunia dan akhirat.

Peranan guru dalam masyarakat antara lain bergantung pada gambaran masyarakat tentang kedudukan guru. Kedudukan sosial guru berbeda dari negara ke nagara, dari zaman ke zaman. Pada zaman Hindu misalnya guru menduduki tempat yang terhormat sebagai satu-satunya sumber ilmu. Murid harus datang padanya untuk memperoleh ilmu. ${ }^{30}$ Berdasarkan kedudukannya sebagai guru ia harus menunjukkan kelakuan layak bagi guru menurut harapan masyarakat. Guru sebagai pendidik dan pembina generasi muda dan masyarakat harus menjadi teladan.

Penyimpangan kelakuan oleh guru akan mendapat sorotan dan kecaman dari masyarakat. Masyarakat tidak membenarkan pelanggaranpelanggaran seperti berjudi, mabuk, pelanggaran seks, korupsi, mengebut dan lain sebagainya terjadi pada guru, bila pelanggaran tersebut sampai dilanggar oleh guru akan dianggap suatu pelanggaran yang sangat serius sekali. Dalam masyarakat kita orang yang lebih tua harus dihormati, Guru lebih tua dari muridnya maka keberadaan guru

${ }^{29}$ Imam Muslim, Shahih Muslim, Jilid II (Al-Maktabatul Mughriyah Kubro), 458.

${ }^{30}$ Nasution. Sosiologi Pendidikan (Jakarta: Bumi Aksara. 1999), 95.

El-Banat Vol. 9. No.2 (2019) 141 
berdasarkan usianya ia mempunyai kedudukan yang harus dihormati, lebih lebih dia dipandang sebagai pengganti orang tua.

Karena kedudukan guru yang istimewa dalam masyarakat mempunyai harapan-harapan tinggi tentang peranan guru, maka harapan-harapan tersebut tidak dapat diabaikan oleh guru. Guru selalu menjadi teladan yaitu sosok yang dapat di gugu dan di tiru bagi anak didik. $^{31}$ Pada umumnya guru tidak menentang harapan-harapan masyarakat walaupun pada hakikatnya membatasi kebebasan mereka. Guru sendiri menerima pembatasan itu sebagai sesuatu yang wajar. Pelanggaran oleh guru juga akan dikecam oleh rekan-rekannya seprofesi. Mereka yang masuk lembaga pendidikan guru pada prinsipnya telah menerima norma-norma kelakuan yang ditentukan oleh masyarakat. $^{32}$

Dalam kehidupan bermasyarakat guru tidak bisa melepaskan dirinya dari masyarakat. Guru adalah anggota masyarakat dan bertanggung jawab ikut serta memajukan kehidupan masyarakat. Untuk memajukan masyarakat guru harus menguasai dan memahami semua hal yang bertalian dengan kehidupan nasional misalnya tentang kehidupan bangsa, adat istidat, kebiasaan, norma-norma, kebutuhan, kondisi lingkungan, dan sebagainya.

Persepsi masyarakat menunjukkan bahwa kompetensi sosial guru berusaha mensukseskan keberhasilan santri dalam proses belajar, guru selalu berusaha berkomunikasi dengan masyarakat lingkungan cukup baik dan harmonis, tidak pernah ada masalah yang mengganggu proses belajar mengajar. Dan apabila ada permasalahan penyelesaiannya melalui pertemuan secara kekeluargaan. guru selalu memperlakukan dirinya secara baik sesuai dengan kepribadian yang utuh. ${ }^{33}$ Sedangkan persepsi masyarakat terhadap guru dalam hal layanan yang berupa kegiatan-kegiatan yang meliputi penciptaan suasana proses pembelajaran, guru sebagai abdi masyarakat melayani dan siap memberikan keterampilan yang dimiliki sesuai dengan kemampuannya selain itu layanan guru sangat bermanfaat bagi masyarakat apabila berupa tambahan pengetahuan dan keterampilan yang dapat meningkatkan kualitas hidup mereka, dan dalam layanan masyarakat perlu dipersiapkan lebih matang mencakup segala kegiatan. ${ }^{34}$

\section{Ghuruh Tolang dan Transformasi Nilai-nilai Agama}

\footnotetext{
${ }^{31}$ Ibid., 96.

${ }^{32}$ Nasution. Sosiologi Pendidikan, 97.

${ }^{33}$ Dwijosumarto, Jurnal Ilmu Pendidikan, Vol. 7, No. 3, (Agustus 2000), 220.

${ }^{34}$ Ibid., 220.
} 
Pembinaan terhadap anak dalam menstransformasikan nilai-nilai agama diperlukan berbagai upaya yang integral. Karena, perkembangan keyakinan akan nilai kebenaran agama pada anak terjadi melalui pengalaman hidupnya sejak kecil, dalam keluarga, disekolah dan dalam masyrakat lingkungannya.

Oleh karenanya, timbul berbagai pertanyaan bagaimana cara memberikan pengalaman keagamaan kepada anak yang akan ikut membentuk pribadinya? Apa yang dapat dilakukan oleh guru dalam proses pembinaan? Untuk menjawab pertanyaan itu, berikut ini akan disampaikan solusi yang diajukan Dzakiah Darajat dan penulis eksplorasi lebih lanjut dari berbagai referensi yang lain.

1. Guru adalah pembina pribadi, sikap dan pandangan hidup anak

Maksud dari pernyataan ini adalah guru sebagai sumber keteladanan dalam segala peilaku kehidupan. Perilaku guru menjadi acuan dalam sikap. Adapun keteladanan dalam pendidikan merupakan bagian dari sejumlah metode yang paling ampuh dan efektif dalam mempersiapkan dan membentuk anak secara moral, spiritualdan sosial. Sebab, seorang pendidik merupakan contoh ideal dalm pandangan anak, tingkah laku dan sopan santunnya akn ditiru, disadari atau tidak, bahkan semua keteladanan itu akan melekat pada diri dan perasaannya, baik dalam bentuk ucapan, perbuatan, hal yang bersifat material, inderawi maupun spiritual.

Meskipun anak berpotensi besar untuk meraih sifat-sifat baik dan menerima dasar-dasar pendidikan yang mulia, ia akan jauh dari kenyataan positif dan terpuji jika dengan kedua matanya ia melihat langsung pendidikan yang tidak bermoral. Memang yang mudah bagi pendidik adalah mengajarkan berbagi teori pendidikan kepada anak. Sedang yang sulit bagi anak adalah mempraktekkan teori tersebut jika orang yang mengajar dan mendidiknya tidak pernah melakukannya, atau perbuatannya tidak sesuai dengan ucapannya. ${ }^{35}$

Keteladanan berasal dari kata dasar "teladan" yang berarti sesuatu yang patut ditiru dan dicontoh. ${ }^{36}$ Dalam bahasa Arab diistilahkan dengan "uswatun khasanah" yang berarti cara hidup yang diridhoi oleh Allah SWT. Sebagaimana yang dicontohkan oleh rosul SAW dan telah dilakukan pula oleh nabi Ibrahim dan para pengikutnya. ${ }^{37}$

${ }^{35}$ Abdullah Nashih Ulwan, Pendidikan Anak Menurut Islam: Kaidah-Kaidah Dasar (Bandung: PT Remaja Rosdakarya, 1992), 1-2.

36 W.J.S. Purwadarmintha, Kamus Umum Bahasa Indonesia (Jakarta: Balai Pustaka, 1993), 1036.

${ }^{37}$ M. Sodiq, Kamus Istilah Agama (Jakarta: CV. Sientarama, 1988), 369.

El-Banat Vol. 9. No.2 (2019) 143 
Dalam dunia pendidikan, formal maupun non formal, ditemukan keragaman bagaimana cara mendidik atau membimbing santri dalam proses pembelajaran. Namun yang terpenting adalah bagaimana orang tua, guru menanamkan rasa iman, rasa cintah kepda Allah, rasa nikmatnya beribadah shalat, puasa, rasa hormat dan patuh kepada oranag tua, saling menghormati atau menghargai sesama, dan sebagainya. Hal itu agak sulit bila ditempuh dengan cara logis atau empiris.

Untuk merealisasikan pendidikan, seorang pendidik dapat saja menyusun sistem pendidikan yang lengkap, dengan menggunakan seperangkat metode atau strategi sebagai pedoman atau acuan dalam bertidak serta mencapai tujuan dalam pendidikan. ${ }^{38}$ Namun keteladanan seorang pendidik sangatlah penting dalam interaksinya dengan santri. Karena, pendidikan tidak hanya sekadar menangkap atau memperoleh makna dari ucapan pendidiknya, akan tetapi justru melalui keseluruhan kepribadian yang tergambar pada sikap dan tingkah laku para santrinya. ${ }^{39}$ Dalam pendidikan Islam, konsep keteladanan yang dijadikan Islam sebagai cermin dan model dalam kepribadian seorang muslim adalah keteladanan yang dicontohkan Rasulullah.

Rasulullah mampu mengekspresikan kebenaran, kebajikan, kelurusan, dan ketinggian pada akhlaknya. Dalam keadaan seperti sedih, gembira dan lain-lain yang bersifat fisik, beliau senantiasa menahan diri. Bila ada hal yang menyenangkan beliau hanya tersenyum. Bila tertawa, beliau tidak terbahak-bahak. Diceritakan dari Jabir bin Samurah: "beliau tidak tertawa, kecuali tersenyum". Jika menghadapi sesuatu yang menyedihkan, beliau menyembunyikan serta menahan amarah. Jika kesedihannya terus beliau pun tidak mengubah tabiatnya, yang penuh dengan kemuliaan dan kebajikan. ${ }^{40}$

Berkaitan dengan makna keteladanan, Abdurrahman AnNahlawi mengemukakan bahwa keteladanan mengandung nilai pendidikan yang teraplikasikan, sehingga keteladanan memiliki azas pendidikan sebagai berikut:

a. Pendidikan islam merupakan konsep yang senantiasa menyeruh pada jalan Allah. Dengan demikian, seorang pendidik dituntut

${ }^{38}$ Ahmad Tafsir, Ilmu Pendidikan Dalam Perspektif Islam (Bandung: Remaja Rosdakarya, 1992), 142.

${ }^{39}$ Hadhari Nawawi, Pendidikan Dalam Islam (Surabaya: Al-Ikhlas, 1993), 216.

40 Ahmad Umar Hasyim, Menjadi Muslim Kaffah: Berdasarkan Al-Qur'an dan Sunah Nabi SAW (Jogjakarta: Mitra Pustaka, 2004), 29.

144 Jurnal El-Banat 
untuk menjadi teladan dihadapan anak didiknya. Karena, sedikit banyak anak didik akan meniru apa yang dilakukan pendidiknya (guru) sebagaimana pepatah jawa "guru adalah orang yang digugu dan ditiru". Sehingga, perilaku ideal yang diharapkan dari setiap anak didik merupakan tuntutan realistis yang dapat diaplikasikan dalam kehidupan sehari-hari yang bersumber dari al-Qur'an dan As-Sunnah. Islam telah menjadikan kepribadian Rasulullah SAW, sebagi teladan abadi dan aktual bagi pendidikan.

b. Islam tidak menyajikan keteladanan ini untk menunjukkan kekaguman yang negatif atau pereningan imajinasi belaka, melainkan islam menyajikannya agar manusia menerapkan pada dirinya. Demikianlah, keteladanan dalam islam senantiasa terlihat dan tergambar jelas sehingga tidak beralih menjadi imajinasi kecintaan spiritual tanpa dampak yang nyata dalam kehidupan sehari-hari. ${ }^{41}$

2. Guru harus memahami betul-betul perkembangan jiwa anak, agar dapat mendidik anak dengan cara yang cocok dan sesuai dengan umur anak.

Menurut penelitian Ernest Harms, perkembangan agama anakanak itu melalui beberapa fase. Ia menyatakan bahwa perkembangan agama pada anak-anak itu melalui tiga tingkatan, yaitu: ${ }^{42}$

a. The fairy tale stage (tingakat dongeng), tingkatan ini dimulai pada yang berusia 3-6 tahun. Pada tingkatan ini konsep mengenai Tuhan lebih banyak dipengaruhi oleh fantasi dan emosi. Pada tingkat perkembangan ini, anak menghayati konsep ke-Tuhanan sesuai dengan tingkat perkembangan intelektualnya. Kehidupan masa ini masih banyak dipengaruhi kehidupan fantasi hingga dalam menghadapi agama pun anak masih menggunakan konsep fantastis yang diliputi oleh dongeng-dongeng yang kurang masuk akal.

b. The realistic stage (tingkat kenyataan), tingkat ini dimulai sejak anak masuk sekolah dasar hingga sampai keusia adolsense.

\footnotetext{
${ }^{41}$ Abdurrahman An-Nahlawi, Pendidikan Islam di Rumah, Sekolah dan Masyarakat (Jakarta: Gema Insani Press, 1996), 263.

42 Jalaluddin, Psikologi Agama (Jakarta: Raja Grafindo Persada, 2001), 66. 
Pada masa ini id eke-Tuhanan anak sudah mencerminkan konsep-konsep berdasarkan kenyataan. Konsep ini timbul melalui lembaga-lembaga keagamaan dan pengajaran agama dari orang lainnya. Pada masa ini ide keagamaan pada anak didasarkan tas dorongan emosinal, hingga mereka melahirkan konsep Tuhan yang formalis. Berdasarkan hal itu maka pada masa ini, anak-anak tertarik dan senang pada lembaga keagamaan yang mereka lihat dikelola oleh orang dewasa dalam lingkugan mereka. Segala bentuk tindak (amal) keagamaan mereka ikuti dan mempelajarinya dengan penuh minat.

c. The individual stage (tingkat individu), pada tingkat ini anak telah memiliki kepekaan emosi yang paling tinggi sejalan dengan perkembangan usia mereka. Konsep keagamaan yang individualistis ini terbagi atas tiga golongan, yaitu:

1) Konsep ke-Tuhanan yang konvensional dan konservatif dengan dipengaruhi sebagian kecil fantasi. Hal tersebut disebabkan oleh pengaruh luar.

2) Konsep ke-Tuhanan yang lebih murni yang di nyatakan dalam pandangan yang bersifat personal.

3) Konsep ke-Tuhanan yang bersifat humanistik. Agama telah menjadi etos humanis pada diri mereka dalam menghayati ajaran agama. Perubahan ini setiap tingkatan dipengaruhi oleh faktor intern yaitu perkembangan usia, dan faktor ektern berupa pengaruh luar yang dialaminya.

Dari keterangan ini, maka para guru perlu memiliki formulasi pembinaan yang tepat ketika melihat perkembangan keagamaan pada jiwa anak-anak, khususnya anak di usia 3-6 tahun.

3. Pendidikan agama pada umur 3-6 tahun, harus lebih banyak percontohan dan pembiasaan.

Secara psikis usia 3-6 tahun dalah usia ingin mencontoh. Yang dimaksud mencontoh atau peniruan disini adalah hasrat yang mendorong anak untuk meniru perilaku orang dewasa, atau orang yang mempunyai pengaruh. ${ }^{43}$ Misalnya dari kecil anak belajar berjalan, berbicara, dan kebiasaan lainnya. Setelah anak bisa berbicara ia akan berbicara sesuai bahasa dimana lingkungan

\footnotetext{
${ }^{43}$ An-Nahlawi, Pendidikan Islam di Rumah, Sekolah dan Masyarakat, 367.
} 
tersebut berada. Pada dasarnya peniruan itu mempunyai tiga unsur, yaitu: a) Keinginan atau dorongan untuk meniru; b) Kesiapan untuk meniru; c) Tujuan meniru. ${ }^{44}$

Sedangkan menurut Abd. Aziz Al Quussy, pada dasarnya peniruan itu mempunyai 2 unsur. Menurut beliau adanya unsur ketiga sudah pasti jika ada unsur pertama dan kedua. Karena unsur ketiga merupakan bertemunya unsur pertama dan unsur kedua. ${ }^{45}$

Untuk lebih jelasnya penulis uraikan satu persatu dari beberapa unsur diatas:

1) Keinginan atau dorongan untuk meniru

Pada diri anak atau pemuda ada keinginan halus yang tidak disadari untuk meniru ornag yang dikagumi (idola) didalam berbicara, bergaul, tingkah laku, bahkan gaya .hidup mereka sehari-hari tanpa disengaja. Peniruan semacam ini tidak hanya terarah pada tingkah laku yang kurang baik.

Ahir-ahir ini gara-gara melihat televisi seperti flm anak langit, banyak anak ingin mengikuti gaya idolanya sehingga banyak anak yang tauran yang menyebabkan cidera, patah tulang, hingga ada yang meninggal. Oleh karena itu, orang tua, pendidik, pemimpin, dituntut selalu membimbing (memberi teladan) pada anaknya. Bagaimana jadinya jika para orang tua, pendidik dan pemimpin tidak bisa menjadi panutan bagi anakanak didik dan ummatnya.

ada sebuah hadist yang diriwayatkan oleh Imam AlBukhori dan muslim dari jalur sanad Abdullah Ibnu Umar, bahwa Abu Bakar berkata:

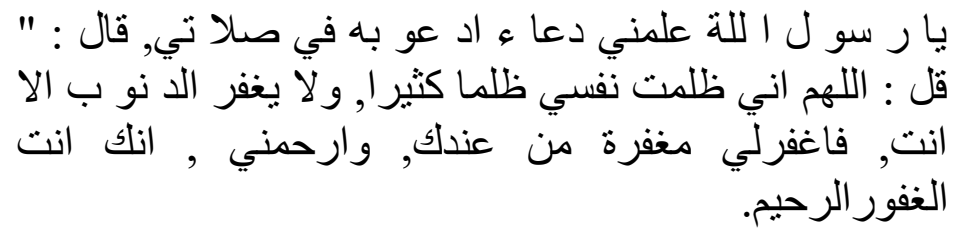

"Duhai utusan Allah, ajarilah hamba suatu do'a yang dengan aku akan brdo'a dalam shalatku, kemudian Nabi bersabda: Katakanlah: Ya Tuhan, Sungguh hamba telah berbuat aniaya terhadap diri hamba sendiri denga perbuatan dhalim yang banyak, dan hanya engkau yang bisa merahmati hamba, karena itu, ampunilah hamba dengan ampunan dari sisi-Mu, dan balas

\footnotetext{
${ }^{44}$ Ibid, 368-371.

45 Abdul Aziz Al Quussy, Ilmu Jiwa, Prinsip-Prinsip dan Implementasinya dalam Pendidikan (Jakarta: Bulan Bintang, 1976), 279.
} 
ksihanilah hamba, sungguh Engkau adalah Dzat Ynag Maha Pengampun lagi Maha Belas kasih". (terjemah bebas penulis). ${ }^{46}$

2) Kesiapan untuk meniru

Setiap tahapan usia mempunyai kesiapan dan potensi untuk meniru. Karena itu, islam tidak mewajibkan bagi anak kecil untuk melaksanakan shalat sebelum mencapai usia 7 tahun (baligh), tetapi tidak melarang anak untuk meniru gerakangerakan shalat yang pernah ia lihat ataupun bacaan dala shalat. Pada prinsipnya, orang tua, guru, pemimpin harus mempertimbangkan potensi anak ketika akan mengarahkan atau membimbing mereka. al-Qur'an sendiri menjelaskan bahwa Allah tidak akan membebani seseorang kecuali sesuai dengan kemampuannya. Ayat yang menerangkan hal tersebut adalah:
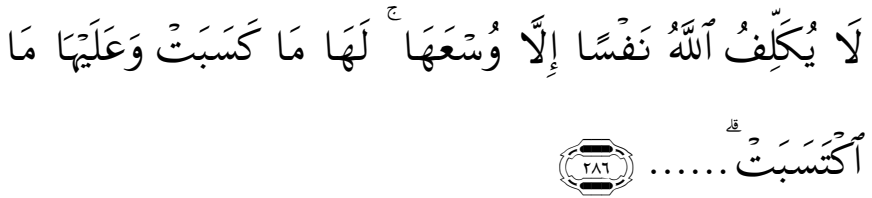

"Allah tidak membebani seseorang melainkan sesuai dengan kesanggupannya. ia mendapat pahala (dari kebajikan) yang diusahakannya dan ia mendapat siksa (dari kejahatan) yang dikerjakannya”. (Al-Baqarah: 286). ${ }^{47}$

Ayat diatas terkait dengan "al-Mas'uliyah al-Syakhsiyah" (tanggung jawab kepribadian). Artinya, setiap diri manusia (terutama yang sudah usia baligh) akan memperoleh dari apa yang dilakukan. Sebagai bandingan (munasab) ayat diatas dapat dilihat pada ayat lain (al-An'am: 164):

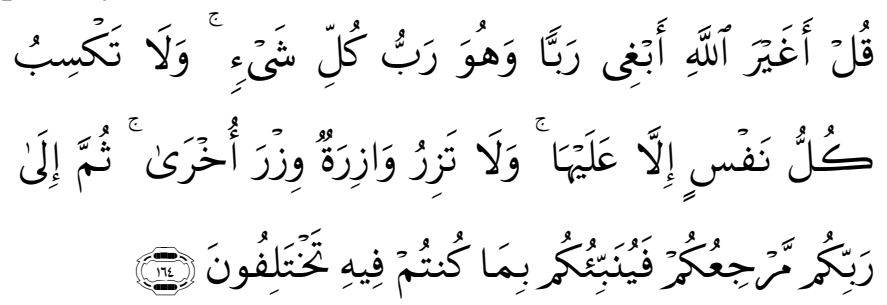

${ }^{46}$ Keterangan tafsirnya dapt dirujuk pada Wahba Zuhaili, al-Tafsir al-Munir, fi alAqidah wa al-Syari'ah wa al-Manhaj. Vol.XI (Daamaskus: Dar al-Fikr, 1991), $442-443$.

${ }^{47}$ Ibid, 88.

148 Jurnal El-Banat 
"Katakanlah: "Apakah Aku akan mencari Tuhan selain Allah, padahal dia adalah Tuhan bagi segala sesuatu. dan tidaklah seorang membuat dosa melainkan kemudharatannya kembali kepada dirinya sendiri; dan seorang yang berdosa tidak akan memikul dosa orang lain. ${ }^{48}$ Kemudian kepada Tuhanmulah kamu kembali, dan akan diberitakan-Nya kepadamu apa yang kamu perselisihkan.".

Menurut riwayat ibnu Mardawaih, dari jalur sanad Ibnu Abbas, ia berkata: Rasulullah SAW ketika membaca akhir surat al-Baqarah dan ayat kursi, beliau tertawa, kemudian beliau bertutur bahwa keduanya merupakan dugang Allah Yang Maha Rahman yang berada dibawah arasy. Kemudian beliau membaca:

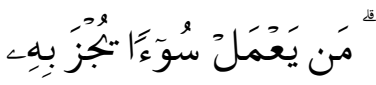

"barangsiapa yang mengerjakan kejahatan, niscaya akan diberi pembalasan dengan kejahatan itu”. (Q.S. An-Nisa':123).

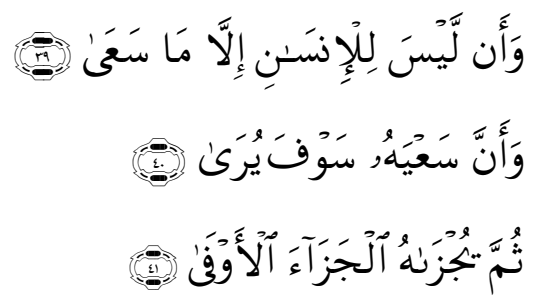

Dan bahwasanya seorang manusia tiada memperoleh selain apa yang Telah diusahakannya. Dan bahwasanya usaha itu kelak akan diperlihat (kepadanya). Kemudian akan diberi balasan kepadanya dengan balasan yang paling sempurna,(Q.S. AnNajm: 39-41).

Salah satu contoh kesiapan manusia untuk meniru adalah bila seseorang mengalami krisis kerena adanya suatu bencana. Orang berusaha mencari jalan keluar untuk melepaskan diri dari krisis yang menimpanya. Pada saat itulah manusia butuh

${ }^{48}$ Maksudnya: masing-masing orang memikul dosanya sendiri-sendiri.

El-Banat Vol. 9. No.2 (2019) 149 
pemimpin yang dipandang mampu dan dapat ditiru dalam kehidupan pribadi maupun sosialnya. Biasanya orang yang ditiru adalah orang yang mempunyai pengaruh, orang yang dipimpin akan meniru pemimpinnya, anak meniru orang tuanya, murid akan meniru gurunya. Menurut An-Nahlawi peniruan yang demikian, dalam istilah pendidikan Islam di sebut dengan "ittiba" (patuh). Dan, ittiba' yang paling tinggi adalah ittiba' yang didasarkan atas tujuan dan cara. ${ }^{49}$

Dari keterangan diatas, dapatlah dipahami bahwa usia 3-6 tahun adalah usia meniru. Karena usia anak 3-6 tahun belum bisa berpikir mandiri maka yang ia usahakan adalah meniru dari kebiasaan manusia sekelilingnya. Oleh karena itu, urgensinya dalam proses pembinaan perlu pendidikan yang pembiasaanpembiasaan yang banyak. Agar dalam mencapai tujuan pendidikan itu sendiri bisa berhasil dan sejalan dengan apa yang diinginkannya.

Latihan-latihan keagamaan yang menyangkut ibadah seperti shalat, do'a, membaca al-Qur'an, harus dibiasakan, sehingga lam kelamaan akan tumbuh rasa senang melaksanakan ibadah tersebut. Dia dibiasakan sedemikian rupa, sehingga dengan sendirinya ia akan terdorong untuk melakukannya, tanpa suruhan dari luar, tapi dorongan dari dalam.

Selain itu, sebagaimana ditulis oleh Muhaimin dalam bukunya paradigma pendidikan Islam, sebuah sekolah yang berusaha menanamkan nilai-nilai keislaman dengan memperbanyak krgiatan-kegiatan diluar jam sekolah seperti khatimul qur'an dan istighasah, ternyata dapat menciptakan suasana ketenangan dan kedamaian dikalangan civitas akademika. ${ }^{50}$ Menurut Dzakiah Darajat, persaan tentram dan lega diperoleh setelah sembahyang, perasaan lepas dari ketegangan batin dapt diperoleh sesudah melakukan do'a dan atau membaca al-Qur'an, perasaan tenang dan berterima kasih dan penyerahan diri, dapat diperoleh setelah melakukan dzikir dan ingat kepada Allah $^{51}$

Dalam penelitian ini menemukan bahwa guru merupakan cermi nan bagi santrinya serta dapt menjadikan diri mereka sebagai contoh yang baik bagi santrinya. Begitu juga kegiatan-

${ }^{49}$ An-Nahlawi, Pendidikan Islam di Rumah, Sekolah, an Masyarakat, 266.

${ }^{50}$ Muhaimin, Paradigma Pendidikan Agama Islam (Bandung: Rosda Karya, 2002), 300.

${ }^{51}$ Darajat, Ilmu Jiwa, 4.

150 Jurnal El-Banat 
kegiatan keagamaan yang dilaksanakan secara terprogram dan rutin bisa menciptakan kebiasaan berbuat baik dan benar menurut ajaran agama yang diyakininya dikalangan mereka.

\section{Peran Ghuruh Tolang dalam Menanamkan Nilai Karakter Islami}

Dari penelitian yang telah peneliti lakukan, diperoleh data bahwa peran ghuruh tolang dalam menanamkan nilai-nilai agama pada santri di Musolla al-Ismail Tlomar Tanah Merah Bangkalan perlu keseriusan dari guru. Hal ini disebabkan karena guru mempunyai bebrapa keahlian dan berusaha supaya nilai-nilai agama yang diajarkan mudah dipahami dan dipraktekkan oleh para santri tersebut.

Pertama: Ghuruh tolang mengajari santri baca al-Qur'an mulai dari mengenalkan huruf hijaiyah sampai bisa membaca al-Qur'an dengan cara dibimbing satu persatu dengan telaten dan penuh kesabaran. Kedua ghuruh tolang menanamkan pendidikan akhlaq pada anak melalui pembiasaan, setiap akan belajar anak disuruh mengucapkan salam pada bapak/ibu guru dan dilanjutkan membaca doa, setiap selesai belajar anak disuruh mengakhiri dengan membaca doa dan dilanjutkan dengan salam, pada saat bertemu dengan bapak/ibu guru menyampaikan ucapan salam, juga terhadap yang lain, apabila akan tidur membersihkan kedua kaki dan kedua tangan serta berdoa dan tidak berisik, apabila sudah bangun berdoa lebih dulu dan merapikan tempat tidur, apabila akan masuk kamar kecil kaki kiri lebih dulu dan membaca doa, jika sudah selesai akan keluar berdoa dan keluar dengan kaki kanan lebih dulu, pada waktu berbicara pada kedua orang tua, bapak ibu guru atau orang lain menggunakan bahasa dengan baik, sopan santun dan menghargai pembicaraan orang lain. Ketiga memberikan bimbingan ibadah/praktek shalat, ghuruh tolang memberikan bimbingan ibadah dengan cara hafalan bacaan-bacaan dalam shalat, melatih santri cara mengerjakan shalat yang benar, selalu mengerjakan shalat berjama'ah magrib dan sholat isya' apabila tiba waktu shalat, menekankan pentingnya mengerjakan shalat, koordinasi dengan orang tua siswa dalam rangka pengawasan yang berkesinambungan terhadap pelaksanaan shalat anak. Keempat Memberikan kasih sayang dan perhatian pada anak dengan cara ghuruh tolang memberikan tugas-tugas rumah atau di sekolah, maka guru mau mengoreksi dan memberikan nilai, guru mengadakan 
pendekatan dan perhatian kepada anak yang mendapatkan permasalahan baik di rumah ataupun di sekolah sertta berusaha mencarikan jalan keluarnya, guru memberikan nasehat pada anak, apabila ingin disayang orang tua, supaya mengikuti apa yang diperintah, menerima dengan senang hati setiap pemberian orang tua. Kelima memberikan contohcontoh yang baik pada anak melalui cara memberikan contoh yang baik pada santri. Menerangkan mata pelajaran menggunakan bahasa yang mudah dimengerti dan dipahami, Berbincang-bincang dengan orang lain atau dengan teman tidak terlontar kata-kata yang tidak baik seperi mencaci maki, menghardik dan membicarakan kejelekan orang lain, ghuruh tolang selalu bertingkah laku baik, memberikan pertolongan kepada orang yang minta tolong, memberikan pertolongan dengan penuh keiklasan, tidak pernah membedakan terhadap orang lain, utamanya pada santri, tidak pernah berlaku sombong, acuh tak acuh terhadap orang lain apalagi muridnya, setiap disapa selalu menjawab dengan penuh perhatian dan banyak senyum. Keenam ghuruh tolang memberikan nasehat yang baik pada anak dengan cara jika ada seorang anak yang salah, maka guru memanggil pada anak tersebut untuk dimintai keterangan pokok permasalahannya, setelah diketahui, maka guru mulai memberikan nasehat dengan sangat bijaksana sehingga anak tidak merasa tersinggung dan mudah untuk menerima, yang akan menyebabkan anak yang salah itu kembali ke jalan yang benar, Setiap anak yang salah, tidak langsung divonis atau dijatuhi hukuman fisik. karena cara yang demikian kurang efektif, oleh karena itu tidak memberikanjalan keluarnya, bagi anak yang salah bisa saja dikenai hukuman, namun hukuman yang bersifat mendidik, dengan cara disuruh membaca surat Al Fatihah sebanyak 20 kali, dengan demikian santri juga mendapat manfaatnnya : 1)Anak dapat menambah kelancaran 2)Anak dapat menambah kefasihan 3) Anak dapat menambah kebaikan atau pahala 4) Anak tidak merasa terbenani (karena sudah hafal).

\section{Kesimpulan}

Peran ghuruh tolang dalam menanamkan nilai-nilai agama prosesnya melalui pengenalan huruf hijaiyah dengan telaten dan kesabaran sampai bisa baca al-Qur'an serta bimbingan ibadah santri 
dengan cara sholat berjamaah memberikan pendidikan akhlaq, memberikan kasih sayang dan perhatian pada santri, memberikan cotohcontoh yang baik pada santri, memberikan nasehat yang baik pada santri, serta melatih santri untuk bertingkah laku menurut ukuran-ukuran lingkungan dimana ia hidup sesuai dengan umur yang dilaluinya. Setelah si anak terbiasa bertindak sesuai yang dikehendaki oleh aturan-aturan moral dan kecerdasan serta kematangan berpikir telah tercapai, barulah pengertian yang abstrak diajarkan. Hal ini penting ghuruh tolang dalam menanamkan nilai-nilai agama pada santri dengan cara mengajari santri baca al-Qur'an mulai dari mengenalkan huruf hijaiyah sampai bisa membaca al-Qur'an, ghuruh tolang menanamkan pendidikan akhlaq pada anak melalui pembiasaan, ghuruh tolang memberikan bimbingan ibadah dengan cara hafalan bacaan-bacaan dalam shalat, melatih santri cara mengerjakan shalat yang benar, selalu mengerjakan shalat berjama'ah magrib dan sholat isya' apabila tiba waktu shalat, menekankan pentingnya mengerjakan shalat, memberikan contoh-contoh yang baik pada anak melalui cara memberikan contoh yang baik pada santri, ghuruh tolang memberikan nasehat yang baik pada anak dengan cara jika ada seorang anak yang salah.

\section{Daftar Rujukan}

Arifin, H.M. Filsafat Pendidikan Islam. Jakarta: Bumi Aksara, 1996.

Hubungan Timbal Baik Pendidikan Agama, Keluarga, dan Sekolah, Jakarta: Bulan Bintang, 1989.

Abrosi,Athiyah. Dasar-Dasar Pokok Pendidikan Islam. Jakarta: Bulan Bintang, 1970.

Darajat,Zakiah. Kepribadian Guru. Jakarta: Bulan Bintang, 1978.

Dwijosumarto. Jurnal Ilmu Pendidikan, Nomor 3, Jilid 7. Agustus. Surabaya, 2000.

Gazalba,Sidi. Sistematika Fisafat, Jakarta: Bulan Bintang, 1978.

Hamdani Ihsan, Fuad Islam, Filsafat Pendidikan Islam, Bandung: CV Pustaka Setia, 2001. 
Hasyim, Ahmad Umar. Menjadi Muslim Kaffah: Berdasarkan Al-Qur'an dan Sunah Nabi SAW, Jogjakarta: Mitra Pustaka, 2004.

Imam Malik bin Anas. Al-Muwatta. Beirut: Dar al-Fikr, $1422 \mathrm{H}$.

Jalaluddin, Psikologi Agama, Jakarta: Raja Grafindo Persada, 2001.

M. Sodiq, Kamus Istilah Agama, Jakarta: CV. Sientarama, 1988.

Ma'arif, Syafii. Islam Dan Pengembangan Ilmu. Yogyakarta: PT. Surya Sarana Utama divisi Grafika, 2003.

Muhaimin, Paradigma Pendidikan Agama Islam, Bandung: Rosda Karya, 2002.

, Pengembangan Kurikulum Pendidikan Agama Islam, Jakarta: PT Raja Grafindo, 2005.

Muhajir, Noeng. Ilmu Pendidikan Dan Perubahan Sosial Suatu Teori Pendidikan, Yogyakarta: Rake Sarasin.

Muslim,Imam. Shahih Muslim, Jilid II, Al-Maktabatul Mughriyah Kubro.

Nahlawi,Abdurrahman. Pendidikan Islam Dirumah, Sekolah Dan Masyarakat, Jakarta: Gema Insani Press, 1996.

Nasution. Sosiologi Pendidikan, Cet. II, Jakarta: Bumi Aksara. 1999.

Nata,Abuddin. Filsafat Pendidikan Islam. Jakarta: Logos Wacana Ilmu, 1997.

Nawawi,Hadhari. Pendidikan Dalam Islam, Surabaya: Al-Ikhlas, 1993.

Quussy,Abdul Aziz. Ilmu Jiwa, Prinsip-Prinsip Dan Implementasinya Dalam Pendidikan, Jakarta: Bulan Bintang, cet. 1, 1976.

Tafsir, at. al., Moralitas Al-qur`an Dan Tantangan Modernitas. Yogyakarta: Gama Media, 2003.

Tafsir,Ahmad. Ilmu Pendidikan Dalam Perspektif Islam, Bandung: Remaja Rosdakarya, 1992.

Thaha,Chabib. Kapita Selekta Pendidikan Islam, Yogyakarta: Pustaka Pelajar, 1996. 
Ulwan,Abdullah Nashih. Pendidikan Anak Menurut Islam: Kaidah-Kaidah Dasar, Bandung: PT Remaja Rosdakarya, 1992.

W.J.S. Purwadarmintha, Kamus Umum Bahasa Indonesia, Jakarta: Balai Pustaka, 1993.

Zuhaili,Wahba. al-Tafsir al-Munir, fi al-Aqidah wa al-Syari'ah wa alManhaj. Vol.XI. Daamaskus: Dar al-Fikr, cet. I, 1991.

http://media.isnet.org/islam/Qardhawi/Masyarakat/NilaiKemanusiaan.html

Mawardi,Imam. Wawancara, Bangkalan 04 Mei 2019.

Yasin,Wahib. Wawancara, Bangkalan 04 Mei 2019.

Ulum,Bahrul. Wawancara, Bangkalan 04 Mei 2019.

Habibuddin,Ahmad. Wawancara, Bangkalan 05 Mei 2019.

Cholik,Abdu. Wawancara, Bangkalan 05 Mei 2019.

Tamam,Badrud. Wawancara, Bangkalan 05 Mei 2019. 